\title{
Disain Kompor Listrik Dengan Menggunakan Pembangkit Listrik Tenaga Surya Untuk Kebutuhan Listrik Rumah Tangga
}

\author{
Sigit Sukmajati ${ }^{1}$; Novi Gusti Pahiyanti ${ }^{2}$ Indrianto $^{3}$ \\ 1,2Institut Teknologi PLN (Fakultas Ketenegalistrikan Energi Baru Terbarukan) \\ ${ }^{3}$ Institut Teknologi PLN (Fakultas Telematika Energi ) \\ ${ }^{1}$ sigit.sukmajati@itpln.ac.id
}

\begin{abstract}
Savings in using electric fuel in the use of fossil fuel electricity must be reduced. This research was conducted as an effort to save the use of electricity by using solar power plants as the main source, with the making of this research it is hoped that it can be used for electricity consumption at a more economical cost and the use of electric stoves can be used in daily life. The selection of materials and this research can be seen from the existing literature and field studies. Solar power plants in this study use some equipment such as solar panels that by utilizing solar energy will be a source of initial voltage, a regulator control battery as a regulator of electric power charging to the battery (battery), battery (battery) as a storage of electrical power, and an inverter for convert the dc to ac voltage from the battery (battery). The equipment is the main equipment used to turn on the electric stove which is the main burden in this application. This research is expected to be a reference for the use of solar energy for electric stoves in an effort to save electricity. This equipment also refers to the amount of power used on an electric stove of $300 \mathrm{~W}$, with an observation time of 7 hours a day, so that it will produce a current that flows at $6.8 \mathrm{~A}$, and a voltage of 17.3 Volts which occurs at 11.00 WIB.
\end{abstract}

Keywords: Electric Stove, Solar Panel, Electric, Household

\begin{abstract}
ABSTRAK
Penghematan penggunaan bahan bakar listrik dalam penggunaan listrik bahan bakar fosil harus dikurangi. Penelitian ini dilakukan sebagai upaya penghematan penggunaan listrik dengan menggunakan pembangkit listrik tenaga surya sebagai sumber utamanya, dengan dibuatnya penelitian ini diharapkan dapat digunakan untuk konsumsi listrik dengan biaya yang lebih ekonomis dan penggunaan energi listrik. kompor dapat digunakan dalam kehidupan sehari-hari. Pemilihan bahan dan penelitian ini dapat dilihat dari studi literatur dan lapangan yang ada. Pembangkit listrik tenaga surya dalam penelitian ini menggunakan beberapa peralatan seperti panel surya yang dengan memanfaatkan energi matahari akan menjadi sumber tegangan awal, pengatur pengatur aki sebagai pengatur pengisian daya listrik ke aki (battery), aki (battery) sebagai penyimpan daya listrik, dan inverter untuk mengubah tegangan dc ke ac dari baterai (battery). Peralatan tersebut merupakan peralatan utama yang digunakan untuk menyalakan kompor listrik yang menjadi beban utama dalam aplikasi ini. Penelitian ini diharapkan dapat menjadi acuan penggunaan energi matahari untuk kompor listrik dalam upaya penghematan listrik. Peralatan ini juga mengacu pada besarnya daya yang digunakan pada kompor listrik $300 \mathrm{~W}$, dengan waktu pengamatan 7 jam sehari, sehingga akan menghasilkan arus yang mengalir sebesar 6,8 A, dan tegangan sebesar 17,3 Volt yang terjadi pada 11.00 WIB.
\end{abstract}

Kata kunci: Kompor Listrik, Panel Surya, Listrik, Rumah Tangga 


\section{PENDAHULUAN}

Saat ini kebutuhan listrik semakin meningkat, walaupun biaya listrik yang semakin mahal tidak akan mengurangi konsumen untuk menggunakan listrik. Hal ini terjadi karena listrik merupakan kebutuhan yang sangat diperlukan dalam kehidupan seharihari, sehingga konsumsi listrik semakin meningkat. Berbagai upaya dilakukan baik untuk kelompok rumah tangga menengah ke bawah maupun rumah tangga menengah ke atas berusaha menekan biaya tagihan listrik per bulan, dengan penggunaan peralatan listrik yang optimal [1].

Energi matahari sebagai sumber energi terbesar di bumi masih jarang dilirik untuk menghasilkan energi listrik. Pemenuhan kebutuhan energi listrik bagi masyarakat terpencil dapat dilakukan melalui penerapan stand alone photovoltaic system (SAPS) yang mengandalkan konversi energi matahari menggunakan modul panel surya [2] [3].

Dengan memanfaatkan sumber daya matahari yang melimpah dalam kehidupan sehari-hari dapat digunakan untuk pembuatan Pembangkit Listrik Tenaga Surya sebagai sumber listrik alternatif yang akan dioptimalkan penggunaannya untuk memenuhi kebutuhan listrik di rumah tangga, serta untuk menyediakan listrik pada kompor listrik sehingga peralatan tersebut akan tetap menyala walaupun catu daya listrik dari listrik PLN tidak aktif (padam) dan dapat digunakan dalam kehidupan sehari-hari. [4] [5] [6]

Berangkat dari hal tersebut, penulis berupaya untuk memanfaatkan energi surya yang memiliki potensi besar untuk kehidupan sehari-hari bagi rumah tangga, dan dapat memberikan keringanan biaya tagihan listrik bagi rumah tangga karena dengan adanya pembangkit listrik tenaga surya, menyediakan ramah lingkungan, dan hasil penelitian ini dapat dinikmati oleh masyarakat [7] [8] [9]. Dengan kenyataan tersebut, pengembangan pembangkit listrik tenaga surya berbasis efek fotovoltaik perangkat sel surya sebagai sumber listrik yang murah, bebas polusi, dan alami menjadi pilihan yang tepat [10] [11] [12]. Namun kenyataan saat ini penggunaan solarcell sebagai sumber listrik masih sangat minim dan belum dapat diandalkan sebagai sumber energi alternatif yang dapat menggantikan listrik [13] [14] [15].

Penggunaan listrik lebih optimal dengan memanfaatkan pembangkit listrik tenaga surya, dan agar masyarakat dapat memahami cara menghemat listrik [16] [17] [18]. Salah satu yang dapat diimplementasikan dalam pemanfaatan energi matahari adalah kompor listrik. Penggunaan mikrokontroler pada kompor listrik menjadi sangat membantu dalam mempermudah pengontrolan besarnya api yang diinginkan [19] [20] [21]. Penggunaan kompor Dengan memanfaatkan energi matahari akan menghasilkan beberapa keunggulan dibandingkan dengan penggunaan kompor lain seperti gas, efisiensinya hampir 58\% [22]. Dengan menggunakan kompor listrik tenaga surya akan mengurangi sebagian pembiayaan yang ada serta pembiayaan tagihan listrik akan berkurang setelah penggunaan pembangkit listrik tenaga surya [23]. Selain itu juga untuk memberikan pemahaman kepada masyarakat agar memahami pengertian ramah lingkungan, agar masyarakat tidak lagi menggunakan kompor konvensional yang menggunakan bahan bakar gas yang dapat merugikan penggunanya, serta dapat mengurangi pemadaman listrik akibat penggunaan listrik yang berlebihan. Pengurangan biaya listrik dengan menggunakan kompor listrik berbahan bakar sel surya akan mengalami pengurangan biaya sebesar 35\% [24]. 


\section{METODE/PERANCANGAN PENELITIAN}

Usulan Sistem yang dirancang untuk menggantikan sistem lama pada perancangan ini adalah sebagai berikut: Metode yang digunakan untuk pembuatan Kompor Listrik dengan Pembangkit Listrik Tenaga Surya, untuk kebutuhan rumah tangga dapat dilihat berdasarkan Gambar 1. di bawah ini:

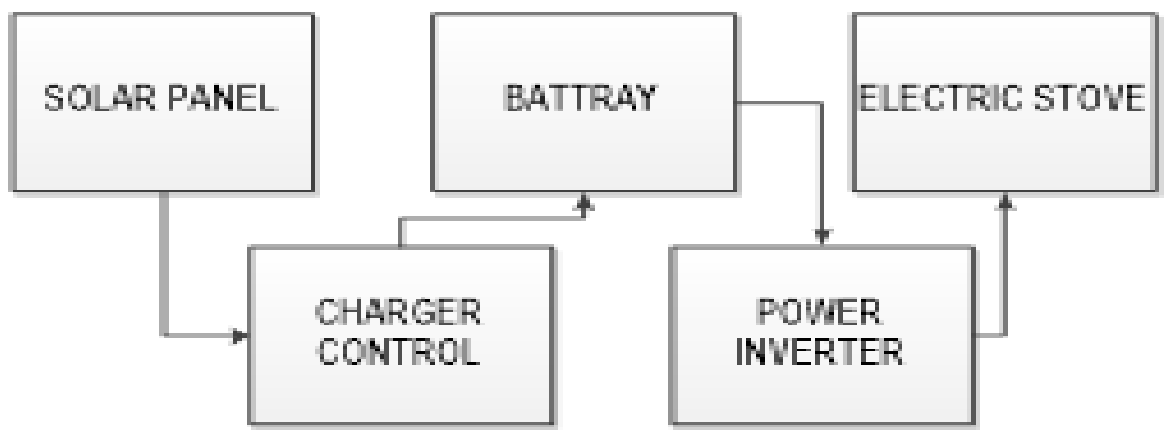

\section{Gambar 1. Rancangan Penggunaan Kompor Listrik Dengan Menggunakan Pembangkit Listrik Tenaga Surya}

Dari gambar 1 akan dibangun kompor listrik dengan 1 daya maksimum 300 Watt. Untuk membangun kompor listrik ini, hal pertama yang harus dimodelkan adalah baterai yang akan digunakan. Untuk alasan ini, model yang diusulkan untuk kapasitas baterai yang digunakan memiliki rumus [25] [26]

Perencanaan PLTS:

Perhitungan Beban Listrik

$\mathrm{Eb}(\mathrm{Wh})=$ Kompor Listrik $(300 \mathrm{w}) \times 3$ jam

$\mathrm{Eb}(\mathrm{Wh})=900 \mathrm{Wh}$

Untuk menghitung beban puncak model digunakan:

Ppeak $=($ Eb $\times$ lo $\times \mathrm{K}) /($ Ho $\times$ Efb $\times$ Eflnv $\times$ Efbcu $)$

$=(900 \times 1000 \times 1,1) /(4500 \times 0,85 \times 0,95$

$\mathrm{x} 1)$

$=272,45 \mathrm{Wp}$

$=990000 / 3633,75$

Dimana:

Ppeak = Kapasitas Pv (Wp)

$\mathrm{Eb}=$ Beban Energi (Wh)

lo = Radiasi Surya Standar (1 kW / m2)

Ho = Rata-rata I Radiasi Surya Indonesia (4,5

$\mathrm{kWh} / \mathrm{m} 2$ / hari)

$\mathrm{K}=1.1$

$\mathrm{EfB}=$ Efisiensi Baterai (0.85)

EfInv = Efisiensi Inverter $(0,95)$

EfBcu = Efisiensi Kontrol Baterai (1) 
Untuk mencapai desain yang diinginkan, diperlukan perhitungan:

$$
\begin{aligned}
\mathrm{N} & =\text { Ppeak } /(\mathrm{PV} \mathrm{PV}) \ldots \ldots \ldots \ldots \\
& =(272,45 \mathrm{Wp}) /(150 \mathrm{Wp}) \\
& =1,82 \\
& =2 \text { Panel }
\end{aligned}
$$

Dimana:

$\mathrm{N}$ = Jumlah PV

Ppeak = Kapasitas PV (Wp)

PVD $=$ Kapasitas PV $(60,80,100,150,200,260,320$

Wp)

Untuk Menghitung Kapasitas Baterai:

K.Baterai $=($ Eb $\times$ Hari Otonomi $) /\left(D D_{\max } \times E f b \times V_{\text {nom }}\right)$.

$$
\begin{aligned}
& =(900 \times 2 \text { hari }) /(0,8 \times 0,85 \times 12) \\
& =220,59 \mathrm{Ah}
\end{aligned}
$$

Dimana:

K.Baterai $=$ Baterai Capacita $($ Ah) Eb $=$ Beban Energi $(\mathrm{Wh})$

D.Otonomi = Daya Cadangan Baterai (Hari)

$\mathrm{DOD}=$ Deep of Discharge $(0.8)$

EfB $=$ Lisensi Baterai $(0.85)$

VBnom $=$ Voltase Baterai $(12 \mathrm{~V})$

Untuk menghitung jumlah baterai:

$$
\begin{aligned}
\text { N.Battery } & =(\text { K.Batt }) /(\text { K.Batt nom }) \\
& =(220 \mathrm{Ah}) /(100 \mathrm{Ah}) \\
& =2.2=2 \text { Baterai }
\end{aligned}
$$

Dimana:

N.Battery = Jumlah Baterai

K.Baterai $=$ Kapasitas Baterai $($ Ah)

K. Nom Baterai $=$ Kapasitas Baterai $(100.150 .200$

Ah)

Untuk menghitung kapasitas Pengisi Daya Surya:

$$
\begin{aligned}
\text { SCC } & =(\text { K.Panel PV) / (Baterai V) } \\
& =(300 \mathrm{Wp}) /(12 \mathrm{~V}) \\
& =25 \mathrm{~A} \text { (Minimum) }
\end{aligned}
$$


Dimana:

SCC $=$ Kapasitas Kontrol Muatan Surya $(A)$

K. Panel PV = Kapasitas PV terpasang (Wp)

Baterai $\mathrm{V}=12$ volt

Perhitungan energi beban:

$\mathrm{K} . \mathrm{INV} \geq \mathrm{Eb}$ (Energi Beban) $=1500$ watt

Metode dalam penelitian ini terdiri dari beberapa kegiatan yang dilakukan seperti menyiapkan bahan penelitian, peralatan penelitian, metode kerja, dan analisis data. Kegiatan penelitian berikut akan dilakukan:

1. Studi Pustaka, melakukan studi analisis data kebutuhan peralatan yang akan digunakan.

2. Studi lapangan, melakukan studi lapangan untuk melihat bagaiamana solar cell akan dipasang atau akan dibuat.

3. Pemilihan kompor listrik, pada desain ini pemilihan kompor listrik dilakukan sesuai dengan keinginan.

4. Dengan desian yang di inginkan, kompor listrik akan dipilih dengan sabaik mungkin sehingga ukurannya sesuai dan mudah dibawa kemana-mana

5. Pemilihan Penel Surya, pada desain ini panel surya yang akan dipilih sesuai dengan kebutuhan kompor listrik yang digunakan, pemilihan panel surya dibutuhkan desai yang baik sehingga

6. Pemilihan Kontrol Pengisian Baterai, pada penelitian ini dilakukan penentuan kontrol pengisian baterai yang diinginkan agar panel surya dapat mengisi baterai.

7. Pemilihan Inverter, peralatan ini untuk mengubah sumber tegangan DC menjadi tegangan $\mathrm{AC}$, disesuaikan dengan daya pada kompor listrik dan baterai (aki).

8. Penentuan Konstruksi Sistem Panel Surya pada rumah tangga.

9. Melakukan pengecekan tegangan keluaran dan arus listrik keluaran pada panel surya (pengisian aki).

10. Melakukan percobaan penggunaan kompor listrik secara langsung melalui aki, dan dilakukan sampai aki tersebut habis.

11. Melakukan pengoperasian dan pencatatan data yang diperlukan.

12. Perhitungan daya secara aktual mengetahui kemampuan kerja kompor listrik dan panel surya.

\section{HASIL DAN PEMBAHASAN}

Untuk merancang model kompor yang dibuat perlu dilakukan penilaian terhadap panel surya dan kebutuhan aki yang digunakan. Berdasarkan hal tersebut maka perlu dilakukan perhitungan perencanaan kompor listrik, maka kami akan mencoba melakukan penelitian kompor listrik dengan 1 buah kompor dengan daya maksimum 300 Watt. Kompor listrik yang diinginkan memiliki desain sebagai berikut:

Sistem kompor listrik ini menggunakan pelat agar panas menyebar. Sehingga akan mematangkan masakan yang ada di dalamnya secara merata. Daya pada kompor listrik ini dapat diatur hingga $600 \mathrm{~W}$ dan memiliki bodi dari plat besi. Panel surya merupakan komponen yang akan menyuplai energi yang digunakan oleh kompor. Panel surya ini merupakan suatu alat yang terdiri dari sel surya yang mengubah cahaya menjadi listrik. Biasanya disebut juga matahari di atas Matahari atau "sol" karena Matahari adalah sumber 
Vol. 11, No. 1, Juni 2021, P-ISSN 2356-1505, E-ISSN 2656-9175

https://doi.org/10.33322/sutet.v11i1.1418

cahaya terkuat yang dapat dimanfaatkan. Panel surya sering juga disebut sel photovoltaic, photovoltaic dapat diartikan sebagai "cahaya-listrik". Sel surya atau sel PV bergantung pada efek fotovoltaik untuk menyerap energi matahari dan menyebabkan arus mengalir di antara dua lapisan bermuatan yang berlawanan. Dari pengukuran yang dilakukan pada panel surya kita mendapatkan:

Tabel 1. Arus Solar Panel

\begin{tabular}{|c|c|}
\hline Waktu & Arus Solar Panel (A) \\
\hline 09.00 & 6,2 \\
\hline 10.00 & 6,4 \\
\hline 11.00 & 6,8 \\
\hline 12.00 & 6,7 \\
\hline 13.00 & 6,5 \\
\hline 14.00 & 6,3 \\
\hline 15.00 & 6,05 \\
\hline
\end{tabular}

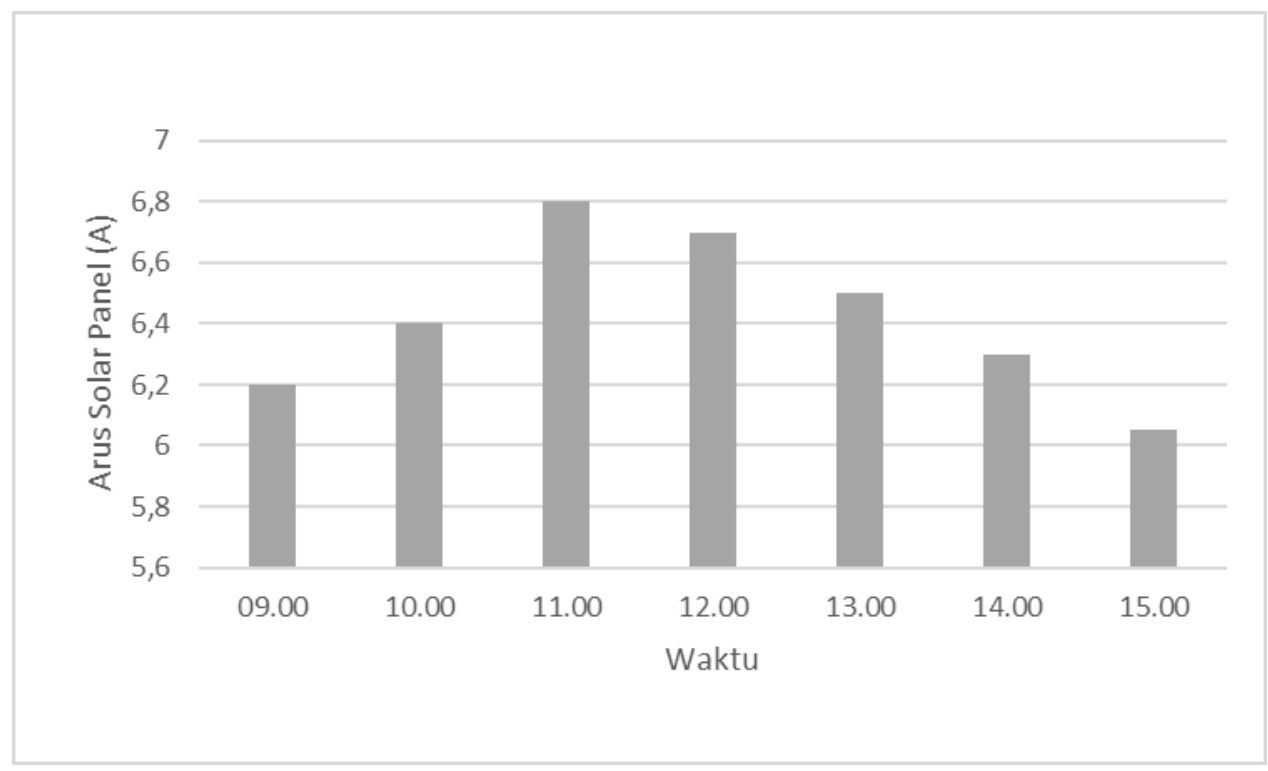

Gambar 2. Grafik Arus Solar Panel

Tabel 2. Tegangan Solar Panel

\begin{tabular}{|c|c|}
\hline Waktu & $\begin{array}{c}\text { Tegangan Solar Panel } \\
(\mathrm{V})\end{array}$ \\
\hline 09.00 & 16,6 \\
\hline 10.00 & 16,9 \\
\hline 11.00 & 17,3 \\
\hline 12.00 & 17,1 \\
\hline 13.00 & 17,03 \\
\hline 14.00 & 16,4 \\
\hline 15.00 & 16,3 \\
\hline
\end{tabular}




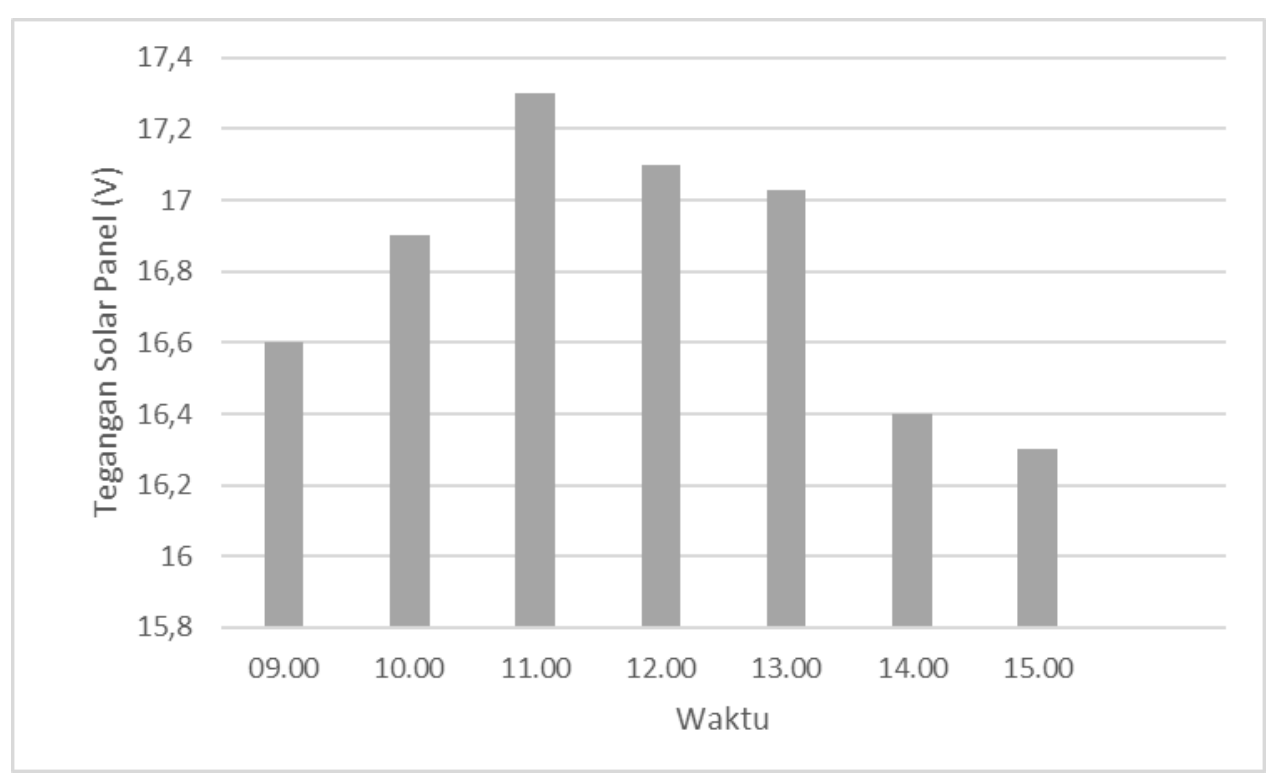

Gambar 3. Grafik Tegangan Solar Panel

Kontrol pengisian baterai di sel surya merupakan komponen penting dalam Pembangkit Listrik Tenaga Surya. Beberapa fungsi solar charge controller adalah untuk mengisi baterai (saat baterai diisi, tetap mengisi jika baterai sudah penuh), dan dapat digunakan pada penggunaan baterai untuk beban (layanan baterai ke beban terputus jika baterai mulai. untuk "mengosongkan"). Pada tulisan ini didapatkan nilai tegangan yang keluar dari pengontrol.

Tabel 3. Tegangan Baterai

\begin{tabular}{|c|c|}
\hline Waktu & $\begin{array}{r}\text { Tegangan Baterai } \\
(\mathrm{V})\end{array}$ \\
\hline 09.00 & 12,2 \\
\hline 10.00 & 12,3 \\
\hline 11.00 & 12,6 \\
\hline 12.00 & 12,4 \\
\hline 13.00 & 12,3 \\
\hline 14.00 & 12,2 \\
\hline 15.00 & 12,1 \\
\hline
\end{tabular}


Vol. 11, No. 1, Juni 2021, P-ISSN 2356-1505, E-ISSN 2656-9175

https://doi.org/10.33322/sutet.v11i1.1418

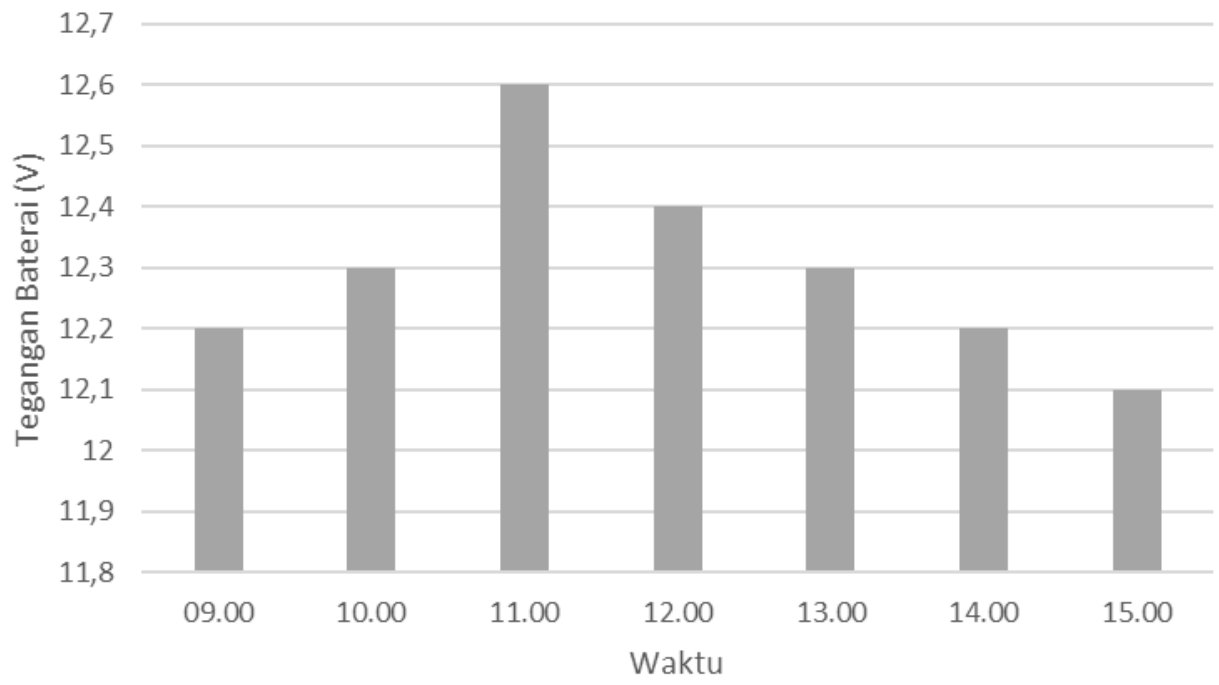

Gambar 4. Grafik Tegangan Baterai

Pengertian inverter secara umum adalah pengubahan tenaga listrik dari arus searah listrik DC (Direct Current) menjadi tenaga listrik arus bolak-balik AC (Alternating Current). Ada beberapa besaran keluaran pada sebuah inverter tergantung dari desain inverter yang jelas inverter akan mengeluarkan daya AC.

Tabel 4. Tegangan Inverter

\begin{tabular}{|c|c|}
\hline Waktu & Tegangan $^{\text {Tnverter }}$ \\
\hline 09.00 & 221 \\
\hline 10.00 & 223 \\
\hline 11.00 & 224 \\
\hline 12.00 & 223 \\
\hline 13.00 & 223 \\
\hline 14.00 & 222 \\
\hline 15.00 & 219 \\
\hline
\end{tabular}




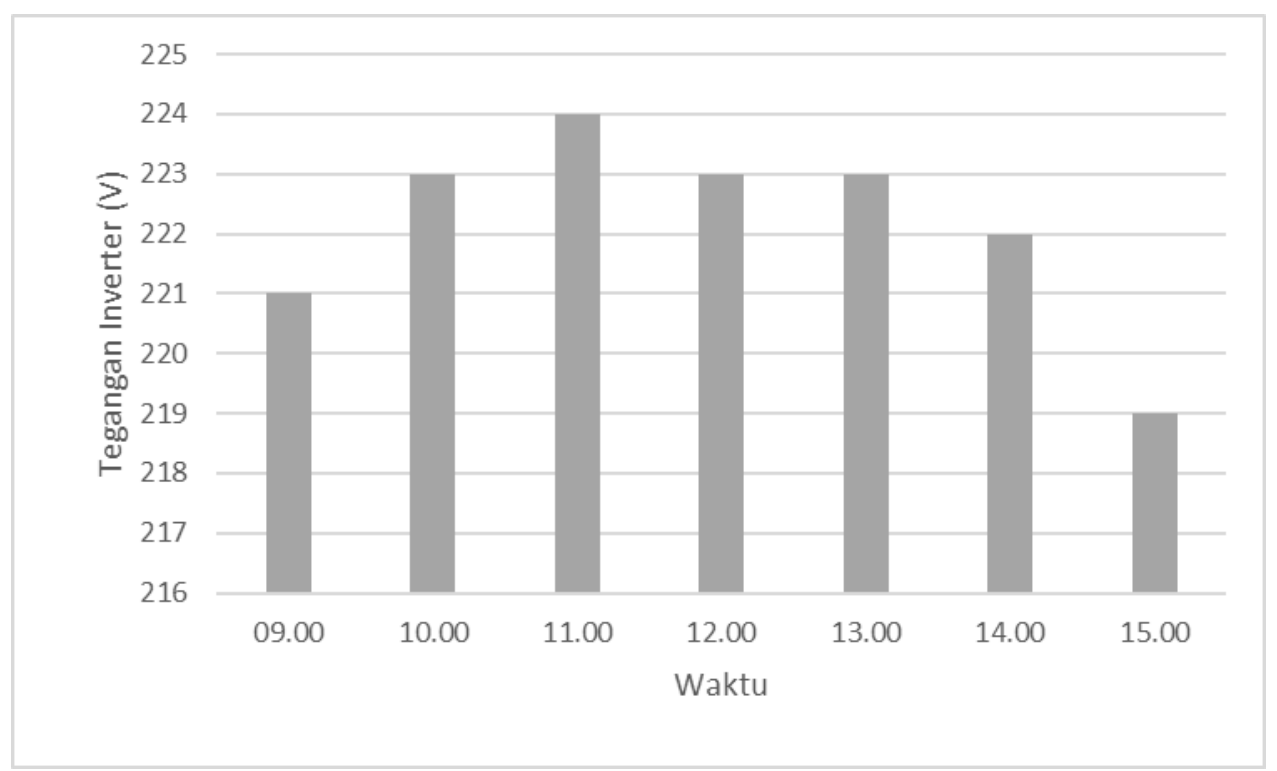

Gambar 5. Grafik Tegangan Inverter

Akumulator (ACCU, baterai) adalah alat penyimpan energi (umumnya energi listrik) dalam bentuk energi kimia. Aki termasuk salah satu yang banyak dijumpai, karena banyak digunakan untuk sepeda atau mobil. Baterai merupakan sel sekunder, karena selain menghasilkan arus listrik, baterai juga mampu mengisi kembali arus listrik. Dalam standar internasional, setiap sel akumulator memiliki tegangan 2 volt, sehingga baterai 12 volt memiliki 6 sel, baterai 24 volt memiliki 12 sel. Baterai hanyalah sebuah sel yang terdiri dari dua elektroda $\mathrm{Pb}$ sebagai anoda dan $\mathrm{PbO}_{2}$ sebagai katoda dengan elektrolit $\mathrm{H}_{2} \mathrm{SO}_{4}$.

\section{KESIMPULAN DAN SARAN}

Secara skema sederhana peralatan yang dibutuhkan dalam penggunaan kompor listrik menggunakan pembangkit listrik tenaga surya yaitu panel surya, pengendali pengisian baterai, inverter dan kompor listrik itu sendiri. Serta menentukan kapasitas inverter panel surya, aki, serta kemampuan kontrol pengisian aki untuk mengisi aki tergantung dari energi yang diserap atau digunakan oleh kompor listrik selama beberapa waktu, dalam penggunaan kompor listrik ini harus diperhitungkan terlebih dahulu berapa lama waktu yang dibutuhkan dalam penggunaannya, sehingga kita dapat menentukan kebutuhan besar kapasitas baterai, dan besarnya kapasitas panel surya yang akan digunakan terutama dalam menentukan ukuran inverter yang akan digunakan. bekas. Pada penelitian ini dimana pada saat ditunjukkan jam 11.00 WIB dihasilkan arus besar 10.6 A, tegangan 6.8 Volt, tegangan battery 17.3 Volt, dan tegangan inverter 224 Volt diamati dalam sehari selama 7 hari.

\section{UCAPAN TERIMAKASIH}

Ucapan terima kasih saya ucapkan kepada pihak terkait yang mendukung selesainya jurnal ini, terutama pada Desa Ciaruteun yang telah memberikan tempat dalam penelitian ini, serta tim yang telah mendukung terselesainya Jurnal ini. diberikan kepada pihak yang berkontribusi dalam hal pendanaan atau fasilitas. 


\section{DAFTAR PUSTAKA}

[1] M. R. Maghami, H. Hizam, C. Gomes, M. A. Radzi, M. I. Rezadad, and S. Hajighorbani, "Power loss due to soiling on solar panel: A review," Renewable and Sustainable Energy Reviews. 2016.

[2] C. Hachem, P. Fazio, and A. Athienitis, "Solar optimized residential neighborhoods: Evaluation and design methodology," Sol. Energy, vol. 95, pp. 42-64, 2013.

[3] M. G. Molina, E. C. Dos Santos, and M. Pacas, "Improved power conditioning system for grid integration of photovoltaic solar energy conversion systems," 2010 IEEE/PES Transm. Distrib. Conf. Expo. Lat. Am. T D-LA 2010, pp. 163-170, 2011.

[4] a P. S. Panel and P. Affairs, "Integrating Renewable Electricity on the Grid A Report by the APS Panel on Public Affairs," Leadership, 2010.

[5] M. Benghanem, "Optimization of tilt angle for solar panel: Case study for Madinah, Saudi Arabia," Appl. Energy, 2011.

[6] T. Tudorache and L. Kreindler, "Design of a solar tracker system for PV power plants," Acta Polytech. Hungarica, 2010.

[7] S. A. Arefifar, F. Paz, and M. Ordonez, "Improving solar power PV plants using multivariate design optimization," IEEE J. Emerg. Sel. Top. Power Electron., vol. 5, no. 2, pp. 638-650, 2017.

[8] C. Y. Tang, S. Y. Ou, and Y. C. Su, "Design and implementation of a hybrid maximum power point tracker in solar power system," in Proceedings of the International Conference on Power Electronics and Drive Systems, 2011, pp. 999-1003.

[9] H. Z. Al Garni and A. Awasthi, "Solar PV Power Plants Site Selection: A Review," in Advances in Renewable Energies and Power Technologies, vol. 1, 2018, pp. 57-75.

[10] L. Miloudi, D. Acheli, and A. Chaib, "Solar tracking with photovoltaic panel," in Energy Procedia, 2013.

[11] H. Kang, T. Hong, S. Jung, and M. Lee, "Techno-economic performance analysis of the smart solar photovoltaic blinds considering the photovoltaic panel type and the solar tracking method," Energy Build., vol. 193, pp. 1-14, 2019.

[12] M. S. Hossain, N. K. Roy, and M. O. Ali, "Modeling of solar photovoltaic system using MATLAB/Simulink," in 19th International Conference on Computer and Information Technology, ICCIT 2016, 2017, pp. 128-133.

[13] T. Y. Hee and M. M. Isa, "Design of a mini solar power system," SCOReD2009 - Proc. 2009 IEEE Student Conf. Res. Dev., no. SCOReD, pp. 300-302, 2009.

[14] D. Karabetsky and V. Sineglazov, "Conceptual Design of Solar Power System," in 2018 IEEE 5th International Conference on Methods and Systems of Navigation and Motion Control, MSNMC 2018 - Proceedings, 2018, pp. 32-35.

[15] C. T. Tsai, Y. B. Muna, H. Y. Lin, C. C. Kuo, and R. Hsiung, "Optimal design and performance analysis of solar power microsystem for mini-grid application," Microsyst. Technol., 2018.

[16] K. K. McCullough, "Sustainable Residential Development: Planning and Design for Green Neighborhoods," J. Am. Plan. Assoc., vol. 74, no. 4, pp. 526-527, 2008.

[17] T. Santala, R. Sabol, and B. G. Carbajal, "OPTIMIZED SOLAR MODULE DESIGN.," Conf Rec IEEE Photovolt. Spec Conf 13th, pp. 733-737, 1978.

[18] G. O. G. Löf and R. A. Tybout, "The design and cost of optimized systems for residential heating and cooling by solar energy," Sol. Energy, vol. 16, no. 1, pp. 9-18, 1974. 
[19] I. Indrianto, M. N. I. Susanti, R. Arianto, and R. Ruli, "Embedded System Practicum Module Design to Increase Student Comprehension of Microcontroller," TELKOMNIKA, vol. 16, no. 1, pp. 53-60, 2018.

[20] R. Ruli A. Siregar, H. Sikumbang, I. B. Sangadji, and Indrianto, "KWh Meter Smart Card Model Token For Electrical Energy Monitoring," MATEC Web Conf., vol. 218, p. 03002, 2018.

[21] I. Sangadji, Y. Arvio, and Indrianto, "Dynamic Segmentation of Behavior Patterns Based On Quantity Value Movement Using Fuzzy Subtractive Clustering Method," J. Phys. Conf. Ser., vol. 974, no. 1, 2018.

[22] S. Chanagala and Z. J. Khan, "Energy efficiency," in Studies in Computational Intelligence, 2019.

[23] G. K. Singh, "Solar power generation by PV (photovoltaic) technology: A review," Energy. 2013.

[24] S. A. Kalogirou, "Environmental benefits of domestic solar energy systems," Energy Convers. Manag., 2004.

[25] M. F. Almi, "Energy Management of Wind/Pv and Battery Hybrid System," Int. J. New Comput. Archit. their Appl., vol. 4, no. 4, pp. 30-38, 2014.

[26] V. Navasare and R. Yanamshetti, "Voltage Regulation Of Hybrid Wind-Solar Energy System," vol. 1, no. 4, pp. 243-247, 2014.

[27] S.Sukmajati, N. Gusti Pahiyanti, ABA Tangkilisan, "Perencanaan Pembangkit Listrik tenaga Surya Di Pos Pengamatan Gunung Soputan," Vol. 8, No. 2, Oktober 2019, PISSN 2089-1245, E-ISSN 2655-4925 